\title{
The Transparencies of Marisa Madieri: Autobiography as FareWELL
}

\section{ERnestina PelLegrin ${ }^{1}$}

\begin{abstract}
Summary: this article analyses Marisa Madieri's narrative with particular attention to its stylistic traits. It focuses on her autobiographical style, characterized by nostalgia and-at the same time-a puzzling and enchanting detachment. Madieri's writing closely looks at the earthly and the physical world from ground level in its minute and marginal aspects, while, at the same time, consistently transcending it. The interplay of memory and farewell, lightly but tenaciously woven into the narrative, informs it with a vertical and metaphysical perspective. Lightness and precision constitute the stylistic elements of her prose, and can be detected in her account of the exodus from post-war Yugoslavia, as well as in her floral fable "La radura," or in the meditative space of her "La conchiglia."
\end{abstract}

What Marisa Madieri has written (short stories, fables, memoirs) could fit into a back pocket. Her entire auvre adds up to around 300 pages, and was written over a period of fifteen years, from 1981 to 1996. Her literary legacy can now be read in two volumes that appeared almost simultaneously in 1998. The first, published by Einaudi, includes her long autobiographical story, Verde acqua, a sort of hybrid between a diary and memoirs, and $\mathrm{La}$ radura, her splendid floral fable from 1992. The Einaudi book, with one of Gauguin's portraits of a woman on the cover, has an illuminating introduction by Ermanno Paccagnini. The second book was published posthumously by the refined and talented editor, Vanni Scheiwiller, who sadly, also disappeared prematurely a few months ago. ${ }^{2}$ The book is enriched by a text by Marisa Madieri's husband, Claudio Magris, who describes his

1 This essay is the translation of "Las transparencias de Marisa Madieri. Autobiografia como despedida" presented at the international conference Prepresentar-representarse. Firmado: muier (a tribute to Zenobia Camprubí), Moguer-Huelva, 25-28 October 2001, and published in the conference proceeding (Huelva: Foundaciòn Juan Ramòn Jimènez, 2001, 605-618).

2 Vanni Scheiwiller (1934-1999) managed from 1951 the Milanese publishing house 'All'Insegna del Pesce d'Oro' and in 1977 set up the 'Libri Scheiwiller'. They are among the most prestigious editorial ventures in post-war Italy. 
recently deceased companion's books as a mix of "epicità e moralità" [epic and morality] written with "la logica ineludibile dei grandi moralisti" [the unavoidable logic of the great moralists] and the "lucidità cristallina dell'intelligenza" [crystalline lucidity of intelligence] (Magris, "Postfazione." Verde acqua, 295, 292). The Spanish edition of Verde acqua contains a beautiful final text by Magris that begins with a quote from Nietzche "Somos profundos, volvamos a ser claros" [Whoever knows he is deep, strives for clarity] (Magris, "Postfazione." Verde agua, 189).

I think it's important to note, in order to understand the style of almost all the stories and especially the pages of the curious mix of diary and autobiography that is Verde acqua, that Marisa Madieri began writing at 40 , in 1981, shortly after discovering the grave illness in her breast that would eventually defeat her, after a 15 year battle. These were 15 full and happy years, during which, as her husband Claudio Magris notes,

non ha lasciato perdere niente, affetti passioni interessi doveri curiosità giochi amicizie piaceri doni di sé agli altri, e ha anche continuato a scrivere le storie che aveva in mente: con amore e con calma, come sempre, senza smania di gareggiare in velocità col male, senza sopravvalutare lo scrivere nella condizione in cui si trovava, ma amandolo fortemente e trasfondendovi l'incanto, il disincanto e la pietas che aveva per la vita e per le cose.

(Magris, "Postfazione." Verde acqua, 293)

[she let nothing go by—affections, passions, interests, duty, curiosity, games, friendships, pleasures, the giving of herself to others-and kept writing the stories she had in mind: with love and tranquility, as always, without worrying about competing with the illness, without overvaluing the fact of writing in her condition, but loving her writing deeply and infusing it with delight and disenchantment, with the pietas she felt for life and things.]

She started to write after leaving her work and with her children grown, that is, when she was able to take stock not only personally, but existentially, from a perspective I would call superior disinterest and almost serene carelessness. At the same time there is great nostalgia and a desire to cling to the beautiful things of the past and the present, a perspective in some ways both internal and external to life, mixing - and this should not seem a paradox or contradiction-impassivity with intense love, and even pity towards the smallest element of reality. Her autobiography is thus a transcendental biography that gestures towards Simone de Beauvoir or Rossana Rossanda's La vita breve, but also in the direction of certain reflec- 
tions by Maria Zambrano on the literary genre from Saint Augustine's Confessions on.

In addition to the two volumes of the complete works, today we also have three pages of an incomplete novel entitled Maria, published in the April 1999 issue of the journal Confini. ${ }^{3}$ It's a fragment written in the third person but with a stylistic development subtly structured through monologues, staging a voice that seems to speak from a perspective of extreme distance, almost from another place, the hereafter. This fragment represents, in my opinion, the last stage of a long meditation, and a contemplation that is marvellous and enchanting, ferocious and melancholy at the same time. The key of meditation allows Marisa Madieri's writing to weave together her autobiography in a subtle play of progressive transparencies and change of planes, and thus, to reach a level of natural transcendence, which allows for the passage, as we will see, towards a genealogical autobiography and thus to an existential autobiography and even a cosmic one, becoming finally an autobiography that is a metaphor for autobiography itself. In this way autobiography becomes the disembodying and lightening of the real, while remaining a meticulous summary of the small and marginal details of life, a humble compilation of what life disperses and takes away. It's a matter - and this is the original core of Marisa Madieri autobiographical style_-of what I would define superficially as a ground-level meditation. In this particular stylistic dosage of nostalgia and detachment what is achieved is a non-contradictory form of enigmatic clarity (in the sense that everything is limpid, as transparent as glass, and like glass, allows the gaze to penetrate beyond, towards a horizon that is enigmatic, mysterious, elusive). In this sense, perhaps, autobiography, in addition to container and mirror of the self, becomes the very possibility of an escape from the self, of the sweet and destructive miseries of contingencies. Because everything is, deep down, an experience of collective memory, everything is - as the author suggests in an interview- "tempo rappreso" [condensed time] (Magris, L'infinito viaggiare, $X V I$ ). Autobiography unwinds this rich and tangled time, putting it perhaps before a mirror and separating it into small chapters that alternate past and present, as happens in Verde acqua, or ordering experience through the selection of important moments and attachments, making the story of one's life a moment of recognition, a gift of memory, and at the same time a gesture of definitive farewell. Meditation, then, as a delicate way of detaching oneself from the world. The narrator of Verde acqua meditates; the daisy of La radura meditates; the woman on the

3 The novel Maria was published by Archinto (Milan) in 2007. 
bus in Aprile meditates; the old native widower of La conchiglia meditates. The text does represent, narrate, but always as if in flight towards a reflective space of meditation. Nevertheless, this meditation does not distance from life, rather, paradoxically, it intensifies a kind of pietas for all living beings, even the most marginal and insignificant.

There, perhaps, originates the punctilious and minute interest in the details of a world seen often from below, at ground level. It's significant, for example, that Verde acqua begins with the image of the child crawling along the hallway of her paternal grandmother's house, her little fingers exploring the table legs, the angles of the furniture, touching in the roughness the "segreti giacigli di polvere" [secret graves of dust] (Verde acqua, 3). Details, low angles, ground level literature and interest in all minimal and marginal forms of life: whether because the perspective is that of a daisy, as in La radura, or because the gaze is of a deformed child still in his mother's womb, as in the short story Il bambino con le ali; or a forgetful old man, old and alone, who feels his strength and memory slip away in an unstoppable haemorrhage of vitality. As a result he buys a great quantity of cans of food and puts them in his cupboards because in the labels he perceives the seduction of life: the red of tomatoes, the nose of a cat, the black of olives, the imperceptible and free flight of a butterfly in a bouquet of flowers. This short story, titled I barattoli, is one of Marisa Madieri's most intense and destructive and in it one can feel a melancholy and tenderness for forms of life that disintegrate and disappear. It's the story of an old widower whose mind empties as he loses all practical interest and begins to feel dazed before the brute sensual happiness restored to him via the labels on cans. "Grandfather Vincenzo" clings to the brute sensuality of all that is completely alive, admiring living things in their simple appearance, as they reveal themselves unconsciously and definitively.

Nevertheless, I wouldn't want what I've said and will say on Marisa Madieri's writing, on the form of autobiography that I would define as a "terminal autobiography," to sound painful, but rather magnificent and arcane (to use Leopardian adjectives), because I believe that her work can be read in different ways. Nevertheless it reveals its full richness and exemplarity when read as phases in a spiritual and cognitive exercise in approaching and domesticating death, as a powerful exercise in metamorphosis and expansion of the self. This occurs in a genealogical perspective that is also social (rooted in this world, in an earthly dimension of familiar and social memory), and which is nevertheless a vertical perspective, infinite, corresponding to a religious and metaphysical point of view. It's a perspective without self-pity or desperation; what's more, it's like a great light, 
remaining clear and high before the unknown and the inevitable pain of separation. There is in it a certain airy lightness and even sly traits, a lightness in which even death can have the grace of a game without losing any of its horror and tragedy. I'm thinking of the ending of La radura, but also a passage from La conchiglia, in which the old native throws stones in the sea, further and further, and watches them as they move through the air, straight and quick, and then slower and inexorably destined to fall:

La loro breve corsa e il grumo di spuma bianca ch'essi provocavano nell'impatto con la superficie dell'acqua, quasi un ultimo spasimo di ribellione prima di essere definitivamente inghiottiti, mi ricordavano la brevità della vita di un uomo e la sua riluttanza a morire.

(La conchiglia, 243)

[Their brief course and the spray of white foam they caused upon hitting the water's surface, almost like a last paroxysm of rebellion before being irrevocably swallowed up, reminded me of the brevity of a man's life and his reluctance to die. $]^{4}$

This double perspective, of light and shadow, this magical and natural play of chiaroscuro contrasts, this extreme dedication to transparency constitute the strength of Marisa Madieri's narration, which is therefore, unilaterally, neither the "soap and water" 5 perspective that Vittore Branca made his own, nor the ink-soaked perspective of the "dark fable," with which I used to read these luminous and melancholy books. This double perspective brings to life the charm of the changing and seductive surface of the world in pages of complete abandon, but also in pages of discovery and acceptance of the necessary and inevitable shipwreck of all living beings, the phenomenon that Marisa always defines with the same word: "engulfed." Man, flowers, music, colours, memories, pebbles thrown in the sea, are engulfed; dreams, kisses, days, footsteps in the sand, engulfed; engulfed the tumultuous and tangled events of our small lives. Here, perhaps, originates the auroral and threshold gaze with which the world is captured, as though we are watching an original being, seeing everything with the astonishment of the first time, while conscious of its ephemeral value. All this is particularly evident in the brio, the sensual force, in the

${ }^{4}$ All English translations of La conchiglia are by Anne Milano Appel, (C 2011. The page numbers refer to the 2006 Einaudi edition (Verde acqua, La radura e altri racconti).

5 "Acqua e sapone" is an Italian idiomatic expression that means fresh and natural, unadulterated beauty. 
vital plenitude that is manifest in the final fragment of La conchiglia, a short story in the form of a monologue. It's the soliloquy of an old Polynesian widower on a volcanic island in the middle of the ocean, who, before the immensity of the sea, remembers the happy moments of his past, the love of his wife, and as he scrutinizes the horizon that joins and blurs the two blue infinities, wants to be "quella linea [blu] per svelare il mistero di ciò che sta oltre" [that [blue] line in order to reveal the mystery of what is beyond] (La conchiglia, 238).

In a mix of impassivity and enthusiasm, but also of unconditional openness to the adventure of life, small eddies of darkness are suddenly created in Marisa Madieri's short stories, subtly worrying enigmas that reveal all the injustice and violence of the world, its banal and foolish vulgarity. They are minuscule gongs of scorn and melancholy. In the protected spaces of these harmonious and vital microcosms (woods, islands, rooms as small as closets, full of memories) dark angles are delineated, dead ends are traced within a mystery completely illuminated by Christian faith, but also by a total religion, a sort of animism that I would define as a cosmic consolation, something so powerful that it demands our humanism do a striptease. A passage from La conchiglia:

Qui sopra vengono innalzati i moai della nostra tribù. Essi hanno le spalle rivolte al mare e con la loro mole sembrano difenderci dalla sua crudele immensità. I loro occhi dall'iride di ossidiana, spalancati e fissi sul villaggio, emettono il mana necessario per la nostra vita e quanto più numerosi essi diventano, tanto più efficacemente il male è tenuto lontano.

Talvolta mi chiedo se una simile posizione, quasi di spregio verso l'oceano infinito, non abbia anche lo scopo di risparmiare alle immagini degli antenati l'insostenibile visione del nulla.

Sono grandi e profonde le notti sulla mia isola. Il buio, che giunge improvviso e si rovescia come una cascata su tutte le cose inghiottendole, avvolge il mistero insondabile della nostra vita in una quiete stellata.

(La conchiglia, 238-39)

[On this pedestal stand the moai of our tribe. They have their backs to the sea and their towering presence seems to defend us against its cruel immensity. Their eyes with the obsidian irises, wide-open, gazing fixedly at the village, emanate the mana necessary to our lives, and the more numerous they become, the more effectively evil is kept at bay. At times I wonder if that imposing stance, almost one of disdain toward the infinite ocean, also served the purpose of sparing our ancestors' images the unbearable sight of nothingness.

Nights on my island are stirring, bottomless. Darkness, which arrives suddenly and spills over things like a waterfall, engulfing them, shrouds the unfathomable mystery of our lives in a star-studded silence.] 
Everything is perceived like this, in a rigorously realist and concrete form, but its representation moves from here to there, agitated, dilated by a pinwheel of truth and mystery. Marisa calls them "piccoli vortici" [small vortexes] (Verde acqua, 7) — she uses the image repeatedly—, small eddies that sink everything into nothingness: the stars, the daisies, the meadows, the clearings, the mountains, the very person who is speaking, in an updown movement that seems to wink with unfathomable tranquility, like an enigmatic liberation from the fear of ceasing to exist.

One of the elements that characterizes this literary prose is the dilation of time and space, in the passage from the representation of a limited dwelling to an ever-broader one, which is a shared memory, a cosmic dwelling, close to metaphysics, in a concentric spiral which on other occasions Marisa refers to-as I've mentioned-as a "sprofondare nel nulla" [sinking into nothingness] by which everything, big or small, transcends into a space larger than what it possesses and loses. In these stories reality is written about, and only reality, but it's as though the roof had been taken off that reality, and suddenly everything is projected in a dizzying vertical tension. A passage from La radura, a floral fable from 1992, in which Daphne the daisy addresses a friend, another daisy named Celeste:

Sai, Celeste, ieri ho fatto un sogno bellissimo e strano. Ero su un grande prato ceruleo, come un cielo rovesciato, in cui al posto delle margherite crescevano tante stelle. Anch'io ero una stella e anche tu. Eravamo adagiate su un fondo molle, nel quale era facile sparire, sprofondando come in un quieto sonno. Ma io non volevo spegnermi e cercavo con fatica di rimanere in superficie. D'improvviso si è alzato un forte vento che, vincendo ogni mia resistenza, mi ha sollevato in un vortice. Mi portava in alto lentamente, in larghi cerchi, oltre le nubi, verso oscure profondità, dove si spalancava, come un pozzo lucente, il volto bianco della luna. E io giravo e giravo precipitando in quell'abisso, fino allo stordimento, fino a non sapere più se ero nuvola, vento, margherita o stella.

(La radura, 38)

[You know, Celeste? Last night I had a beautiful but strange dream. I was in a cerulean meadow, like an inverted sky, where instead of daisies, stars grew. Even I was a star, and you were too. We were resting on a soft ground, where it was easy to disappear, to let yourself fall as if into a calm dream. But I didn't want to be extinguished and I struggled to stay on the surface. Suddenly a fierce wind started to blow and, overcoming all my resistance, raised me up in a vortex. It was carrying me in the air slowly, in wide circles, beyond the clouds, towards dark depths, where the moon's white face, like a shining well, opened wide to me. And I was spinning and spinning headlong in that abyss, until I was dazed, until I no longer knew if I was cloud, wind, daisy or star.] 
Let me quote now from one of the first diary fragments from Verde acqua, an original autobiographical work where fragments of diary and childhood memories are face to face as in a mirror. These fragments from childhood speak of the plenitude of daily family life, with its thankless tasks and holidays, and the exodus of the family from Fiume (Rijeka) to Trieste. At the core of this autobiography, then, is the theme of exodus, with the image of the small cells of the Silos, "un edificio immenso di tre piani, costruito sotto l'impero absburgico come deposito di granaglie, con un'ampia facciata ornata da un rosone e due lunghe ali" [an immense three-storey building, built during the Hapsburg Empire as a granary, with a wide façade decorated with a rose window and two wings] (Verde acqua, 67-68) that accommodated thousands of refugees from Istria, Dalmatia, and Rijeka. They are images of violence and poverty, of vital enchantment, of moral disdain and evangelical rebellion. I quote this passage because it clearly enunciates this sense of deep time, of time re-encountered, emerging in small vortexes from an obscure and disregarded depth, to become on the page a mosaic that gives life to an autobiography perceived and understood as a great exodus. Autobiography as exodus. I quote it as well because the most notable function of the micro-stories Marisa Madieri narrates is perhaps the dilation of time:

25 novembre 1981.

La profondità del tempo è una mia recente conquista. Nel silenzio della casa, la mattina quando rimango sola, ritrovo la felicità del pensare, del ripercorrere avanti e indietro il passato, dell'ascoltare il fluire del presente. È qualcosa che avevo raramente conosciuto prima. [...] Dal mondo del lavoro, con i figli già piuttosto grandi, sono stata restituita alla libertà della mia casa e delle mie giornate. Nell'umile e vario lavoro quotidiano i pensieri possono affiorare, organizzarsi, chiarificarsi. Il tempo, prima quasi senza dimensioni, ridotto a mero presente da una vita frettolosa, incalzata da un turbinio di doveri, di gioie strappate e di affanni, ora si distende in ore leggere, si dilata e sprofonda, si popola di risonanze e ricordi che a poco a poco si ricompongono a mosaico, emergendo in piccoli vortici da un magma indistinto, che per lunghi anni s'è andato accumulando in un fondo buio e inascoltato.

(Verde acqua, 7)

[25 November 1981.

The profundity of time is my most recent conquest. In the silence of the house, in the morning, when I find myself alone, I re-encounter happiness in thinking, in ranging forward and backwards towards the past, in listening to the flow of the present. It's something I only rarely experienced before [...] From the work world, with my children more or less 
grown, I've been restored to the freedom of my house and my days. In my humble and varied daily work, thoughts can emerge, organize, and clarify. Time, previously almost without dimension, reduced to the present of a hurried life pursued by a whirlwind of responsibilities, surreptitious joys and urges, now extends in light hours, dilates and deepens, fills with resonance and memories that little by little come together like mosaics, emerging in small vortexes from an indistinct magma that has been accumulating in a dark and disregarded depth.]

Years ago I stole a definition that Manganelli used for Nabokov, and described Marisa Madieri's books as "fatti di sughero" [made of cork] (Pellegrini, Le città interiori, 131); so light is the touch, so simple the craft of her style that Paccagnini defines them as stories "in punta di lapis" [of the point of a pencil] (Verde acqua, XX).

Marisa mines the surface of the world, observes the external, caresses and surrounds the face that things offer us, leaving them intact. Paccagnini has highlighted the rich terminology of a style that is a phenomenology of epiphany (words like: occur, listen, admire, contemplate, marvel, seduction, surprise, charm, mystery), a lexical repository that produces what could be called a mysticism of materiality, material being the core of visible and invisible forces. The primary stylistic tone, the melody that carries the writing, is auroral, as though things, even the most humble, the most mediocre, were discovered for the first time in their fleeting apparition. We are before the gratuitous demonstration of the world, there to be admired and described; a world where hierarchies are unknown. The description proceeds through parataxis, made of "and," proceeding from the virtually limitless addition of this and that. It's the strategy of a discreet aesthetic, achieved by elevation, by abrasion, an aesthetic made of lentissimi, pauses, whispers, silences, diffuse colours, the unsaid, tones that are low but tenacious, the narrating voice lowering its volume as it seeks the music of the world (what Marisa calls "il più vasto e arcano concerto delle cose ( $\mathrm{La} \mathrm{radu-}$ $r a$, 54) [the widest and arcane concert of things]), aiming to return to the writing that is before writing, exactly the opposite of experimental bravado. The style is sober, resulting from a labour of pruning that responds to two fundamental rules: lightness and precision.

In these stories radical questions take root, questions like "Where do living things come from?" "Where do they go?" "Does the sea have an end?" Everything is said and written with the spontaneity (feigned, at least) of a natural occurrence. The daily becomes the mirror of eternity, perhaps what Laforgue defined as "eternullity," or eternal nothingness. But in this continual reflection between existence and mystery, Marisa doesn't allow 
the spell of illusion to advance, but rather puts into action what I would call "illuminismo curvilineo" [curvilinear illuminism], to steal a phrase Claudio Magris used in Danubio (288).

A few years ago, in a book of mine entitled Le città interiori, I published a study of Marisa's first two books, analyzed through the metaphors of the garden, the flower and the abode, at the heart of which I perceived the figure of Penelope, who weaves and undoes the fabric of her own dilated and impenetrable time. Garden, flowers, dwellings, a feminine mythology of fertility, with its tree-like alphabet projecting the maternal shadow of secrecy. Today I'd add the symbol of the shell, which comes to be part of this maternal constellation, traversing Marisa Madieri's stories time and time again. We find it, in fact, not only in La conchiglia itself, but in Riccardo e la sirena, in which the relationship between the daughter and mother figure is made explicit in the end when a photograph of the mermaid-mother is found, its corner completely encrusted in shells. Thus the sketch of the last novel, Maria, returns, the protagonist seeing something "luminoso e cangiante" [luminous and iridescent] (Maria, 7) in the greenish pools of the sea closed off by breakwaters, "un inatteso arcobaleno sotterraneo" [an unexpected subterranean rainbow] (Maria, 7).

In the rest of her xuvre, Marisa Madieri makes frequent use of the metaphor of the garden and flowers. The garden can be understood as the space of origin and memory (like Eden), or as the space of return and hope (like paradise), and mythically it can be seen as the "epiphany of the feminine" in the triple representation of the Goddess in the figures of Demeter (the Mother), Kore (the daughter) and Hecate (Death), all related in different ways to vegetation and to a cyclical conception of natural transformation. Madieri's gardens, from the many in Verde acqua to the stormy one in Aprile, a story published in a small miscellaneous volume with the title Pagine come gocce and now included in La conchiglia e altri racconti (1998), do not share the melancholic delicacies of the "hortus conclusus" of D'annunzio's heavenly gardens, nor do they resemble the wild orchards of the crepuscolari, which exude the oblique enchantment of decadence, although we perceive the importance of the contrast between the ordered beauty of the garden tended by man and the threat of spontaneous and wild flowering, configured in La radura in the "pericolo giallo" [yellow peril] (La radura, 42) of dandelions. Marisa Madieri feels the whole obscure charm of this threat, of this self-propagation of inevitable sterility:

Dafne quel giorno capì per la prima volta che il mondo non apparteneva solo alle margherite. I soffioni, che le erano sempre piaciuti con i loro petali color dell'oro e i soffici palloncini trasparenti, pronti a sfaldarsi e a 
liberare al minimo alito di vento i semi maturi, potevano diventare concorrenziali e pericolosi.

(La radura, 46)

[That day Daphne understood for the first time that the world didn't belong only to the daisies. The dandelions, which she'd always liked, with their golden petals and their soft little transparent globes, ready to open and liberate their mature seeds at the slightest breath of wind, could become competitive and dangerous.]

We need to turn to another writer to find the full expression of the attraction to the aesthetic transgression of the crepuscolare and decadent model, that is, of the abandoned garden, and the garden gone wild, the disorderly invasion of weeds, and the confirmation of "la dignità altresì morale del loro esistere" [the dignity and even morality of their existence] (Manzini, 58). That is Gianni Manzini in Ritratto in piedi:

Erbacce, perché l'uso vuole che si distruggano? Nascono condannate le erbacce ... Perché ti umilia questo eccesso gratuito di impulso vitale? ... Esuberanza povera povera ... e perciò vedi com'è pietoso questo far gruppo, questo avvincere ....

(Manzini, 58-59)

[Weeds, why does custom want to destroy them? These weeds are born condemned ... Why are you humiliated by this gratuitous excess of vitality? ... Poor, poor exuberance ... and through them you see the sorrow in this way of being a group, of binding ....]

Daphne, the daisy of La radura, can be classified in this key, within an inventory of imagined flowers - from Goethe's "original plant" to Novalis' blue flowers, from the symbolists' pale lilies to Rilke's anemones, whose too-open petals cannot close, and open fully "per contenere il mondo" [to contain the world] (La radura, 78).

It is curious to observe how the nexus of identification between the "I" and flowers appears in many autobiographical works by Twentieth century writers. I'm thinking of Neera's Una giovinezza del XIX secolo; Ada Negri's Stella mattutina; Grazia Deledda's Cosima; Sibilla Aleramo's Una donna; Delia Benco's Ieri. There are the "orti lontani" [distant vegetable gardens], the "piccoli verzieri sepolti nell'ombra di una fitta vegetazione" [small gardens buried in the shadow of thick vegetation] of Neera (3); the "gigli nel sole" [lilies in the sun] of Ada Negri (21); "le raccolte di fiori ideali" [the collection of ideal flowers] of Sibilla Alerano (18); the "gigli sciu- 
pati dal vento" [lilies shrivelled by the wind] of Grazia Deledda (34); the "vegetazioni degradanti, paurose, che debbono far cambiar rotta ai miracoli, all'impreveduto, alla gioia di vivere" [withered vegetation, so frightening that it makes change course to miracles, to the unpredictable and to the joy of life" of Delia Benco (170). But, to reach writings closer to us, what comes to mind are the "giardini incorruttibili" [incorruptible gardens] of Cristina Campo (33), Anna Maria Ortese's winter gardens, Sara Virgillito's deformed Botticellian springs, Antonia Pozzi’s worrying gardens enclosed by rusting fences, and finally "il giardino ingombro di vasi" [the garden made obstacle by planters] of Elsa Morante's Diario from 1938, with "bellissimi fiori rosa, pieni e molli" [beautiful, full and humid pink flowers] (11). Following the metaphor, and to get out of the Italian countryside, I want to direct my readers at least to Colette's stories, in which "occhi infantili forano il buio" [children's eyes perforate the darkness] (Laure, 16), where "il giardino dell'infanzia" [the garden of childhood] revolves around "parenti e dottori" [doctors and relatives] and around "alla fossa dei pazzi" [the pit of the mad] (Laure, 16): "Le mie corone di fiori di campo, ritrovate sul volto degli eroi; i fiori di serra e i fiori di melo, in cimitero: ciarpame funerario" (Laure, 29) [my garland made of wildflowers, rediscovered on the face of heroes; the flowers of the greenhouse and the flowers of the apple tree, in the cemetery: funerary rubbish]."

La radura is an emblematic text in this reading of the metaphor of the garden. I'd like now to give a synthetic description of this text, which for me is, along with La conchiglia, the most beautiful that Marisa Madieri has written. Through a delicate circling of her work, I'd like also to show how the author, within this curious form of metaphoric autobiography (an autobiography dilated to a cosmic dimension), lets the whole of life through, with its paralyzing riches, of seasons, schools, illness, love. And right now a short work of Raymond Roussel called La vue (1904) comes to mind because of its similarity. In the book Roussel represents a seaside resort that can be seen through the glass ball of a penholder.

I think that with the story of Daphne's sentimental education, the daisy of that delicate dark fable of 1992, Marisa Madieri discovered and accepted her share of darkness. The title alludes, perhaps unknowingly, to echoes of Heidegger. I read this fable as a story of metamorphosis. The perspective is of a young daisy, whose name, Daphne, refers instantly to a rewriting of the classic myth of the metamorphosis of a nymph, who, running from Apollo's erotic advances, becomes a laurel branch. It brings to mind Sonnet 12 of Rilke's Sonnets to Orpheus that begins: "Will transformation. O be inspired for the flame" and concludes: "Every fortunate space 
that the two of them pass through, astonished, / is a child or grandchild of parting. And the transfigured Daphne, / as she feels herself become laurel, wants you to change into wind" (157). ${ }^{6}$

But what also comes to mind, precisely because of the re-writing of the feminine myth that I referred to above, is a text entitled "Nymph" in Feminist Fables by the Indian writer Suniti Namjoshi. In fact, Marisa Madieri's fable shares an exploratory vein with some interesting contemporary writers, mostly American, who re-write myths and classical tales from the point of view of the female characters (for example the Odyssey from Circe's perspective.) I'm thinking of Transformations by Anne Sexton or Adrienne Rich's Dream of a Common Language, in which there is a search for utopia, for the hereafter (the part of Dreams), in order to deconstruct intellectually and symbolically and allow denuded reality to speak a de-grammatized grammar, which belongs, clearly, to the Common Language. Thus, La radura can also be read as a rewriting of the myth of Daphne, and is a story of utopia and its inevitable disenchantment expressed in the "common language." In this respect the final image of the book is significant: the girl crowned as a queen, but only for an afternoon and as part of a game, with a garland of daisies, an image that inverts the coronation of the God Apollo with a garland of evergreen laurel.

The gardens of Marisa Madieri are clearings, that is, spaces without trees or grasses, and they are mirrors of our earthly condition. The daisy of La radura is represented as a humble and sober literary species, like the daisy of Andersen's tale, like Leopardi's shrub on the Vesuvio, like Saba's dead leaves, like certain lichens in Sbarbaro.

Daphne is in a clearing that is nothing special, but rather "any meadow," with small uneven mounds and a well of "stagnant water" in the middle (we are outside the literary ideal), that reveals the immutable laws of life, the battles between biological species, the decline of the old, the natural cataclysms, the inevitable end of everything. Initially she rebels against this, while a part of her opens to the night, to its mysterious inhabitants, and she plays with her own shadow that is never quite the same, that perhaps belongs to the realm of fairies, of fantasies and dreams. At the same time, Daphne belongs to the life of this small polis of plants, which has its feminists demonstrations and its meetings of the wise senate, its love lives and schools, and she learns, especially, that social life is the story of accidents, of tormentors and the tormented, and for a moment she feels the

6 Rilke, Duino Elegies. The first verse in the Italian version cited by the author refers more explicitly to metamorphosis: "Punta alla metamorfosi. Infiammati per la fiamma." (Translator's note) 
pride of her floral condition- "Solo le margherite non mangiavano nessuno" [Only daisies didn't eat anybody] (La radura, 52) - but also an "un'indicibile nostalgia [...] per i giorni già lontani della sua vita in cui tutto era mistero e avventura" [indescribable nostalgia [...] for the now distant days when everything was mystery and adventure] (La radura, 55). She feels nostalgia as well for "il regno della libertà" [the reign of liberty] (La radura, 58) that is literature, where everything grows in a possible and reversible moment. But Daphne welcomes-and this is the cause of destruction of the fable itself - the fact that literature, in addition to being "lo specchio della bellezza" [the mirror of beauty], must also be "il regno della verità" [the realm of truth] (La radura, 59), so that, for her, to tell the sad story of a bird fallen from a nest means you have to speak of the snake that ate it, to give voice to the vulgarity, the horror, the banal cruelty of life. The refusal to create a cold eternal symbol (a garden abandoned in glass) is revealed by the fable within the fable entitled "Cuore di pietra" [Heart of Stone] (La radura, 69): it's the story of a white stone that, after having felt the warmth of a squirrel's body, and having been led down the garden path by its incautious love for this living being, renounces its own immortality. Here again is the double meaning of construction and deconstruction of dwelling which is evident, especially, in chapter 30 and in the final one, in which the end for Daphne, who has grown, and for the very narration, can only be the projection of self, that shadow, in the form of a girl, with her fears and her dreams, her bitter purity, a girl who is crowned queen for an afternoon with a garland of daisies.

Plucked from her meadow, Daphne dies, and the weak voice that gives a consistency of wind and music to those extreme sensations is a sublime celebration of a dream of virginal purity (and we can see the daisy as an echo of Goethe's Faustian Margarita.) But for Marisa Madieri the flower's end makes sense only when reflected in the eyes of the child. And here it is important to underline the change in perspective from the daisy to the child, in a relationship of reciprocity and reversal:

Mentre le ultime voci andavano spegnendosi, sempre più fioche e lontane, la bambina dai capelli bruni ricomparve all'improvviso. Si fermò a fissare, con gli occhi d'ambra ridivenuti pensosi, la conca affondata nell'ombra. Tolse dal capo la ghirlanda di fiori che l'aveva quel giorno incoronata regina e la depose delicatamente su un cespuglio.

Si allontanò infine furtiva, sollevando nella corsa la gonna, azzurra e leggera come l'ala di una farfalla.

Dafne non lasciò mai la sua radura.

(La radura, 86) 
[As the last voices were fading, ever weaker and distant, the girl with the dark hair reappeared suddenly. She stopped for a moment to stare intently, her amber eyes once again pensive, at the hollow engulfed in darkness. She took off the garland that had crowned her queen that day, and delicately left it on a bush.

She went away furtively in the end, and as she ran she raised her skirt, blue and light like the wing of a butterfly.

Daphne never left her clearing.]

This relationship of reciprocity and reversal is fundamental in Marisa Madieri's writing. It is mainly present in the final image of the daisy chain (Daphne, Camilla, Rachele, Amanda ...) but also in so many women who, through the generations, held hands in Verde acqua, in the great gallery of female portraits (from Nonna Quarantotto to Nonna Anka, from the mother to the sister, Lucina), a portrait gallery that, I would argue, forms the spine of the whole narration, to the final portrait of the mother's face as she dies.

Small stories of regular lives, of resistance and challenge to life's difficulties, that communicate the full and epic meaning, transpersonal and dizzying, of existence seen from the long view, in the passage of generations, in the cyclical passage of seasons and the years, where everything ends and jointly continues, continues in others and in the memory that is left behind. And it is with this image of reciprocity and solidarity that I'd like to end, with a quote from an extreme moment, let's call it that, in $\mathrm{La}$ radura:

[Dafne, il fiore strappato] Si sentì sollevare, scuotere, stringere e infine adagiare, in un solido abbraccio con altre compagne, su un cedevole giaciglio.

Dov'era l'umida e compatta zolla materna? Dove lo spazio definito e rassicurante in cui era cresciuta? Dove la luce chiara del sole che la riscaldava? Tutto era d'un tratto vago, spento, indecifrabile, immerso in un presente stagnante e vischioso. Era questa la fine del tempo? E i frutti e i semi? Oh Celeste, falli anche per me.

— Si, — le parve di udire, — anche per te, amica mia, anche per te.

(La radura, 85)

[Daphne, the cut flower] felt herself rise, be shaken, squeezed and finally reclined, in a solid embrace with other companions, on a soft bed.

Where was the humid and compact maternal earth? Where was the defined and calming space in which she had grown up? Where was the clear light of the sun that had warmed her? Everything seemed imprecise, extinguished, indecipherable, immersed in a stagnant and viscous pre- 
sent. Was this the end of time? And the fruits and seeds? Oh Celeste, make them for me as well.

Yes, she thought she heard, for you as well, my friend, for you as well.

\section{UNIVERSITY OF FLORENCE}

Translated by Dominique Russell

\section{CiTed Works}

Aleramo, Sibilla. Una donna. Roma-Torino: Società tipografico-editrice nazionale, 1906.

Benco, Delia. Ieri. Milano: Ceschina, 1937.

Campo, Cristina. La tigre Assenza. Milano: Adelphi, 1991.

Deledda, Grazia. Cosima. Milano: Treves, 1937.

Laure (Colette Peignot). Storia di una ragazzina e altri scritti. Roma: Edizioni delle donne, 1976.

Madieri, Marisa. La radura, Torino: Einaudi, 1992.

—. La conchiglia e altri racconti. Milano: Scheiwiller, 1998.

- Verde acqua, La radura e altri racconti. Torino: Einaudi, 2006.

—. Maria. Milano: Archinto, 2007.

Magris, Claudio. Danubio. Milano: Garzanti, 1986.

—. Postfazione a Marisa Madieri. La conchiglia e altri racconti. Milano: Scheiwiller, 1998, pp. 62-73.

—. Postfazione a Marisa Madieri. Verde agua. Barcellona: Editorial Minuscula, 2000.

Linfinito viaggiare. Milano: Mondadori, 2005.

Manzini, Gianni. Ritratto in piedi. Milano: Mondadori, 1971.

Morante, Elsa. Diario 1938. Torino: Einaudi, 1989.

Neera (Anna Zuccari). Una giovinezza del XIX secolo. Milano: Cogliati, 1919.

Negri, Ada. Stella mattutina. Milano: Mondadori, 1921.

Paccagnini, Ermanno. Introduzione to Marisa Madieri, Verde acqua, La radura e altri racconti. Torino: Einaudi, 2006. pp. v-xxi.

Pellegrini, Ernestina. Le città interiori. Bergamo: Moretti \& Vitali, 1995.

Rilke, Rainer Maria. Duino Elegies and The Sonnets to Orpheus. Ed. and trans. by Stephen Mitchell. New York: Vintage, 2009. 